\title{
Successional trajectory of the fouling community on a tropical upwelling ecosystem in southeast Rio de Janeiro, Brazil
}

\author{
Bruno Pereira Masi ${ }^{1}$, Ricardo Coutinho ${ }^{1}$, Ilana Zalmon ${ }^{2 *}$
}

\author{
${ }^{1}$ IEAPM - Instituto de Estudos do Mar Almirante Paulo Moreira \\ (Divisão de Biotecnologia Marinha, Rua Kioto 253, 28930-000, Arraial do Cabo, RJ, Brasil) \\ ${ }^{2}$ UENF - Universidade Estadual do Norte Fluminense - Centro de Biociências e Biotecnologia \\ (Av. Alberto Lamego 2000, 28013-602, Campos, RJ, Brazil) \\ *Corresponding author: ilana@uenf.br
}

Suporte Financeiro: CNPq/FAPERJ/PRONEX under Grant E-26/111.438/2010

\begin{abstract}
The present study describes the successional trajectory of the fouling community in the upwelling region of Cabo Frio in southeastern Rio de Janeiro, Brazil. For 12 months, five PVC panels were sampled monthly by underwater photography to record the percent cover of fouling organisms, which allowed for the evaluation of the successional process through functional groups. The variability in the composition of the fouling community increased throughout the successional trajectory, creating a mosaic pattern. The identification of two associations after a year of observation, with one characterized by filamentous algae, Hydrozoa and Cirripedia and another mainly by articulated calcareous algae, shows that divergent trajectories can be observed even under the same environmental conditions. As an important seasonal factor of the local oceanographic characteristics, the upwelling events allowed for an environmental heterogeneity, and rejecting the classic orderly and directional succession model.
\end{abstract}

Descriptors: Fouling Community, Succession, Upwelling, Temperature.

\section{RESUMO}

O presente estudo descreve a trajetória sucessional da comunidade incrustante na região de ressurgência de Cabo Frio no sudeste do Rio de Janeiro, Brasil. Durante 12 meses, cinco painéis de PVC foram amostrados mensalmente por fotografia subaquática para registrar a porcentagem de cobertura dos organismos incrustantes, permitindo a avaliação do processo sucessional através de grupos funcionais. A variabilidade na composição da comunidade incrustante aumentou ao longo de toda a trajetória sucessional, criando um padrão de mosaico. A identificação de duas associações após um ano de observação, sendo uma caracterizada por algas filamentosas, Hydrozoa e Cirripedia, e outra principalmente por algas calcáreas articuladas, evidencia que diferentes trajetórias podem ser observadas inclusive quando iniciadas sob mesmas condições ambientais. Como um importante fator sazonal das características oceanográficas locais, os eventos de ressurgência favoreceram uma heterogeneidade ambiental, rejeitando o clássico modelo sucessional ordenado e direcional.

Descritores: Comunidade Incrustante, Sucessão, Ressurgência, Temperatura. 


\section{INTRODUCTION}

A large number of studies on the interface between benthic ecology and oceanography have identified a number of the major coastal phenomena that can control or shape the organization of benthic communities (reviewed by WIETERS et al., 2009). Coastal upwelling is one of these phenomena, and it occurs when deep, cold and nutrient-rich waters reach the surface near the coast (VALENTIN, 1987).

In general, the effect of coastal upwelling on the benthic community can be divided into three aspects. The first one concerns of larval dispersal (MIRATAI et al., 2008; PINEDA et al., 2007; PINEDA et al., 2010). The physical mechanisms involved in larval transport to the coast encompass a wide range of temporal and spatial scales and include upwelling, winds and surface currents, linear internal waves and internal tidal bores (LADAH et al., 2005). The second aspect is related to nutrient enrichment and the availability of suspended particles in the water column as an upwelling result. Food availability is one of the critical environmental factors that affect the dynamics of benthic filter feeding organisms (COMA et al., 2000). The third aspect is temperature variation, one of the most important factors for the regulation of biological processes in ectothermic organisms (KORDAS et al., 2011). Therefore, these aspects may play an important role in the successional process of benthic communities (MCCOOK; CHAPMAN, 1997; MENGE et al., 2004; WIETERS et al., 2009).

Critical reviews of successional trends and mechanisms (DRURY; NISBET, 1973; PICKETT et al., 1987) as well as results of studies performed in aquatic environments (SUTHERLAND; KARLSON, 1977; FARRELL, 1991; DRAKE, 1991) contradict the traditional interpretation of the successional process: under the same abiotic conditions and with the same species stock, the equilibrium community will be achieved over time.

Fouling communities provide a useful system for the study of ecological succession because space is a limiting and easily defined resource, experimental manipulation is relatively easy, and there is an exchange of species for short periods of time (DEAN; HURD, 1980, BRAM et al., 2005).

In Cabo Frio, which is in southeastern Rio de Janeiro, Brazil, the phenomenon of seasonal upwelling of cold water from the south occurs with lower water temperatures $\left(<18{ }^{\circ} \mathrm{C}\right)$ during spring and summer and higher water temperatures during fall and winter, which characterizes the non-upwelling period. The present study tests the hypothesis that distinct successional trajectories are created when fouling associations initiated under the same conditions are subjected to seasonal upwelling water masses.

\section{MATERIAL AND METHODS}

The present study was conducted on Cabo Frio Island ( $23^{\circ} 00^{\prime} 04^{\prime \prime}$ S, $\left.42^{\circ} 00^{\prime} 20^{\prime \prime} \mathrm{W}\right)$, Rio de Janeiro State, southeastern Brazil on a small sandy cove surrounded by rocky shores (Figure 1) where upwelling events are frequent and intense and are caused by prevailing northeast winds and topographical and geographical characteristics of the seabed and shore line. VALENTIN et al. (1987) showed the importance of local winds on the fluctuation of the thermocline. Discrete upwelling events may occur throughout the entire year but are more intense and frequent during the spring and summer months when a marked thermal dome forms just below the surface (reviewed by GUIMARAENS et al., 2005). Sedimentation rates in the upwelling zone of Cabo Frio range from 0.26 to 0.66 mm.year-1 (MAHIQUES et al., 2005).
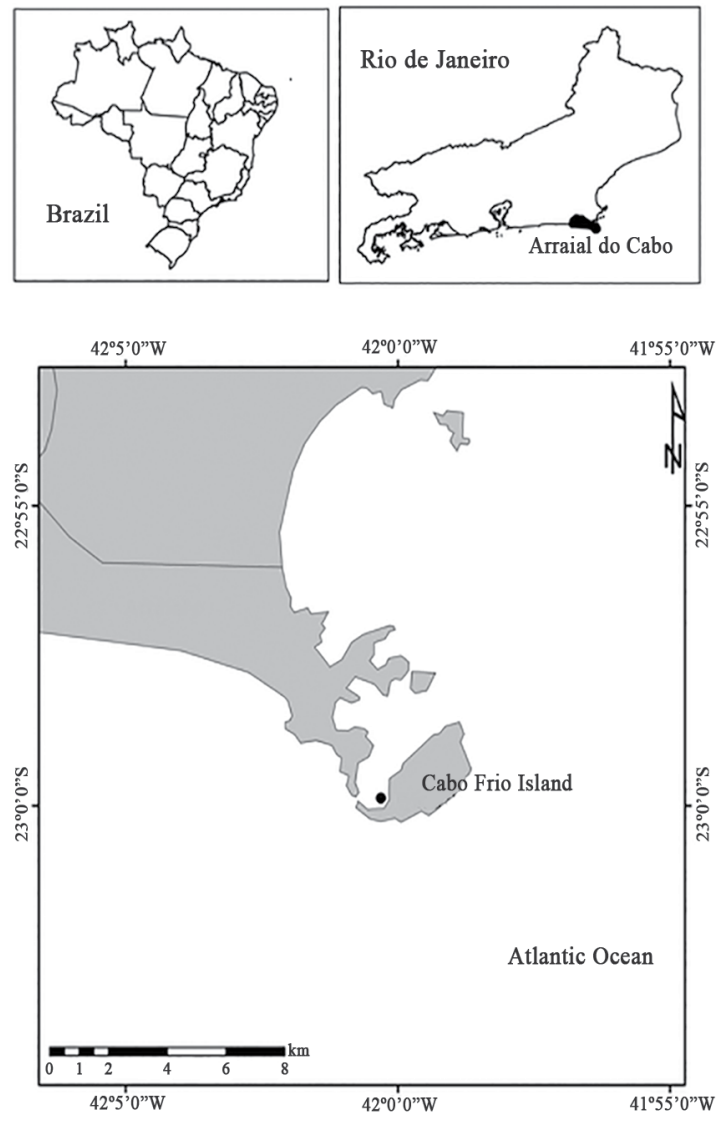

Figure 1. Location of the study site (x) on Cabo Frio Island, Rio de Janeiro State, southeastern Brazil. 
The non-upwelling period in Cabo Frio is characterized by warm waters that occur during fall and winter and have temperatures generally above $21^{\circ} \mathrm{C}$ and nutrient concentrations of nitrate and phosphate are below 1 and $0.4 \mu$ g-at.-, respectively. Temperatures below $18{ }^{\circ} \mathrm{C}$ and sometimes as low as $13{ }^{\circ} \mathrm{C}$ and high nitrate and phosphate concentrations of approximately 10 and $0.8 \mu \mathrm{g}$-at.1-1 respectively, characterize the upwelling conditions (GUIMARAENS et al., 2005). Therefore, by continuously recording temperature, it is possible to identify the occurrence of water masses with distinct characteristics throughout the year.

\section{EXPERIMENTAL DESIGN}

Five multi-experimental units fixed to the bottom of the ocean individually supported experimental PVC panels $(20 \times 15 \mathrm{~cm})$ arranged horizontally at $3.5 \mathrm{~m}$ depth (Figure 2). Each multi-experimental unit consisted of a PVC tube (5 $\mathrm{m}$ height and $20 \mathrm{~cm}$ diameter) held on a concrete block weighing approximately $350 \mathrm{~kg}$. The multi-experimental units were placed $10 \mathrm{~m}$ apart from each other and parallel to the shoreline.

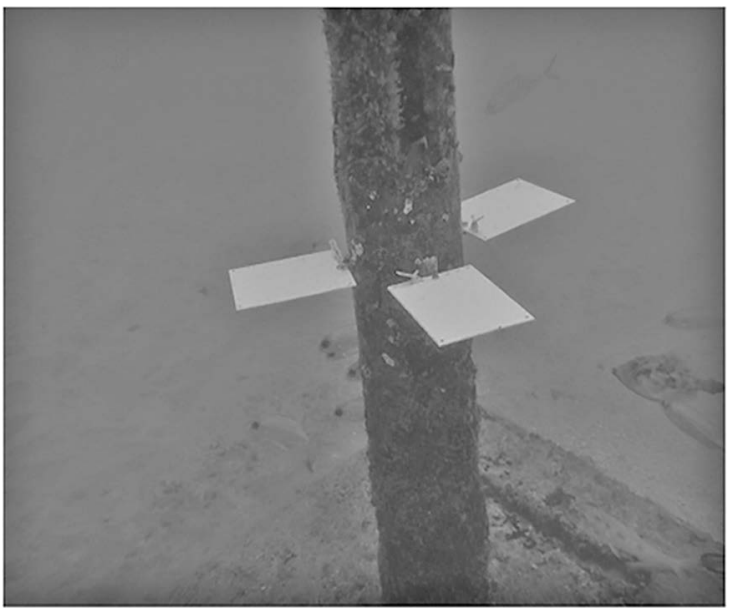

Figure 2. Biofouling multi-experimental units used in the present study to support the PVC panels.

\section{TEMPERATURE}

The presence of distinct water masses temporally distributed in the water column was assessed using DS1921H/Z Thermochron iButton sensors that recorded the temperature at every hour at the exact experimental depth over the entire period of panel immersion. The accuracy of the sensors was tested and showed an error of $\pm 0.5^{\circ} \mathrm{C}$.

\section{FoULING COMMUNITY}

The experimental panels $(\mathrm{N}=5)$ were immersed in July 2009 , and the fouling community was monthly sampled for a 12-month period. Divers performed a non-destructive sampling of five panels (one from each experimental unit) through in situ photography, which avoided the possible effects panel manipulation and provided a permanent photographic record of the data. The photographs were taken with a DC1200 SeaLife 12-megapixel digital camera in macro mode, which is designed for short and fixed distances.

The photographs were analysed using the software Coral Point Count with Excel extensions (CPCe) (KOHLER; GILL, 2006). A rectangular area was selected in the digital image, which was overlaid with 100 points distributed into a grid (10 lines and 10 columns), and the percentage of points that covered each functional group was estimated. Thus, the relative abundance of the biota was calculated and subsequently transformed $(\operatorname{arcsen} \sqrt{ } \mathrm{x})$.

The taxonomic nomenclature followed the Integrated Taxonomic Information System (ITIS, 2009). Based on STENECK; DETHIER (1994) and DE MESSANO et al. (2009), the following functional or discrete taxonomic groups were defined: Biofilm 1, Biofilm 2, articulated calcareous algae, crustose algae, filamentous algae, sponges, Hydrozoa, bivalves, Cirripedia and encrusting bryozoan. Biofilms 1 and 2 were differentiated by the identification of the main biofilm organism. Crustose coralline algae (Corallinales, Rhodophyta) were identified only as a functional group.

\section{STATISTICAL ANALYSIS}

Temperature was evaluated using the number of upwelling events measured at each month studied.

The comparative analysis of the biofouling community included a cluster analysis (UPGMA) and non-metric multidimensional scaling [nMDS] with a Bray-Curtis similarity coefficient for the percent cover of arcsine $\sqrt{x}$ transformed data of the representative species (CLARKE; WARWICK, 2001). An analysis of similarity (ANOSIM) permutation test was used to evaluate the significance of the differences between the community successional stages. Units sampled in the same month were treated separately to increase the permutation possibility and, consequently, the power of the test (CLARKE; WARWICK, 2001). The species' contributions to the similarity percentage (SIMPER) were calculated using the identification of fouling associations (CLARKE; 
WARWICK, 2001). Multivariate analyses were performed with PRIMER v.6 software.

\section{RESULTS}

\section{TEMPERATURE}

The temperature records indicated the occurrence of a typical year of seasonal upwelling $(\mathrm{N}=259$ events) with temperatures in the study area equal to or less than $18^{\circ} \mathrm{C}$ from September 2009 to March 2010, which corresponded to the $2^{\text {nd }}-8^{\text {th }}$ months, respectively, of panel immersion (Figure 3a, b).
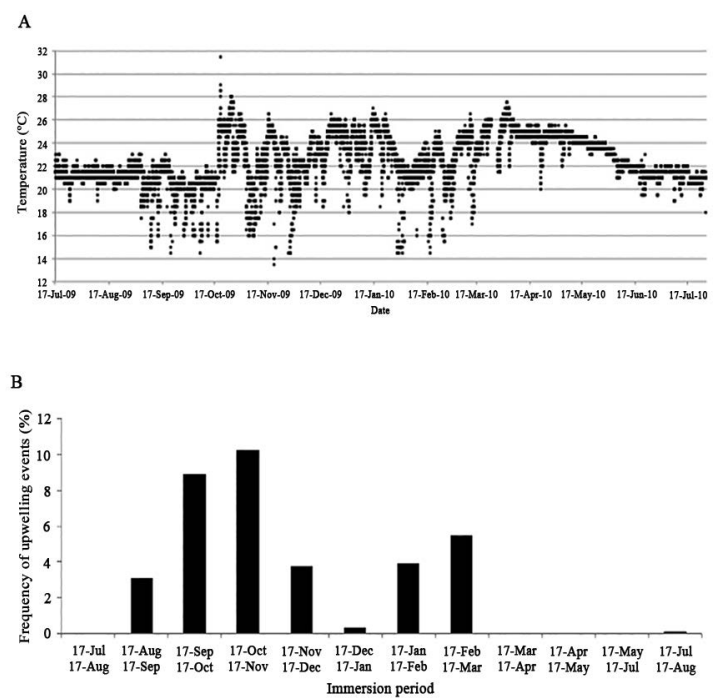

Figure 3. Daily temperature values recorded at $3.5 \mathrm{~m}$ of depth (A) and relative frequency of upwelling events (B) over the period of immersion of experimental panels at Cabo Frio Island.

\section{TRAJECTORY OF THE FOULING COMMUNITY}

Over the 12 months, 21 taxa were identified, comprising two diatoms, four macroalgae and 15 macroinvertebrates (Table 1). The most represented functional groups ( $>10 \%$ coverage in any sampling monthly) were Biofilm 1 , Biofilm 2, articulated calcareous algae, filamentous algae, sponges, Hydrozoa, bivalves and Cirripedia. Crustose algae and encrusting bryozoans were the rarest groups $(<10 \%)$.

The mean percent cover of the functional groups along the successional trajectory indicates the relative abundances in the 12 months of immersion (Figure 4). Biofilm 1 predominated in month-1, filamentous algae dominated from month-2 to month-6, and Biofilm 2 dominated from month-7 to month-10. In later months, articulated calcareous algae, Hydrozoa and sponges were the most abundant groups (Figure 4).
Table 1. Taxonomic (invertebrates) and functional (algae) groups recorded on the experimental panels at Cabo Frio Island from July 2009 to July 2010.

\begin{tabular}{|c|c|}
\hline Taxon & Functional group \\
\hline \multicolumn{2}{|l|}{ Diatom } \\
\hline Nitzschia $\mathrm{spp}$ & Biofilm 1 \\
\hline Navicula spp & Biofilm 2 \\
\hline \multicolumn{2}{|l|}{ Macroalgae } \\
\hline \multicolumn{2}{|l|}{ Division Rhodophyta } \\
\hline Jania sp. & Articulate calcareous algae \\
\hline Order Corallinales & Crustose algae \\
\hline \multicolumn{2}{|l|}{ Division Phaeophyta } \\
\hline Family Ectocarpaceae & Filamentous algae \\
\hline \multicolumn{2}{|l|}{ Macroinvertebrate } \\
\hline \multicolumn{2}{|l|}{ Phylum Porifera } \\
\hline Amorphinopsis sp. & Sponge \\
\hline Dysidea etherea & Sponge \\
\hline Oceanapia nodosa & Sponge \\
\hline Mycale microsigmatosa & Sponge \\
\hline \multicolumn{2}{|l|}{ Phylum Cnidaria } \\
\hline Pennaria sp. & Hydrozoa \\
\hline Obelia dichotoma & Hydrozoa \\
\hline \multicolumn{2}{|l|}{ Phylum Mollusca } \\
\hline Perna perna & Bivalve \\
\hline \multicolumn{2}{|l|}{ Phylum Arthropoda } \\
\hline Megabalanus coccopoma & Cirripedia \\
\hline Balanus amphitrite & Cirripedia \\
\hline Balanus trigonus & Cirripedia \\
\hline \multicolumn{2}{|l|}{ Phylum Ectoprocta } \\
\hline Schizoporella errata & Encrusting bryozoan \\
\hline
\end{tabular}

The ordination of the sampling units by immersion time (1 to 12 months) shows an increasing dispersion starting in the seventh month with divergent successional trajectories (Figure 5). Two fouling associations were identified starting at month-10. In one association (two experimental panels: $\mathrm{S} \Delta=55 \%$ ), the groups that contributed to this similarity were Hydrozoa (41.82\%), Cirripedia (30.91\%) and filamentous algae (18.8\%). The other association (three panels: $\mathrm{S} \Delta=59.33 \%$ ) was composed of articulated calcareous algae (79.21\%) and Hydrozoa (7.3\%). The mean dissimilarity between the two associations was higher than $70 \%$, which was primarily the result of the articulated calcareous algae $(41.57 \%)$, filamentous algae (20.31\%), sponges (12.47\%) and Hydrozoa (10.45\%).

The cluster analysis of the fouling community at each stage initially separated the community into two parts: 


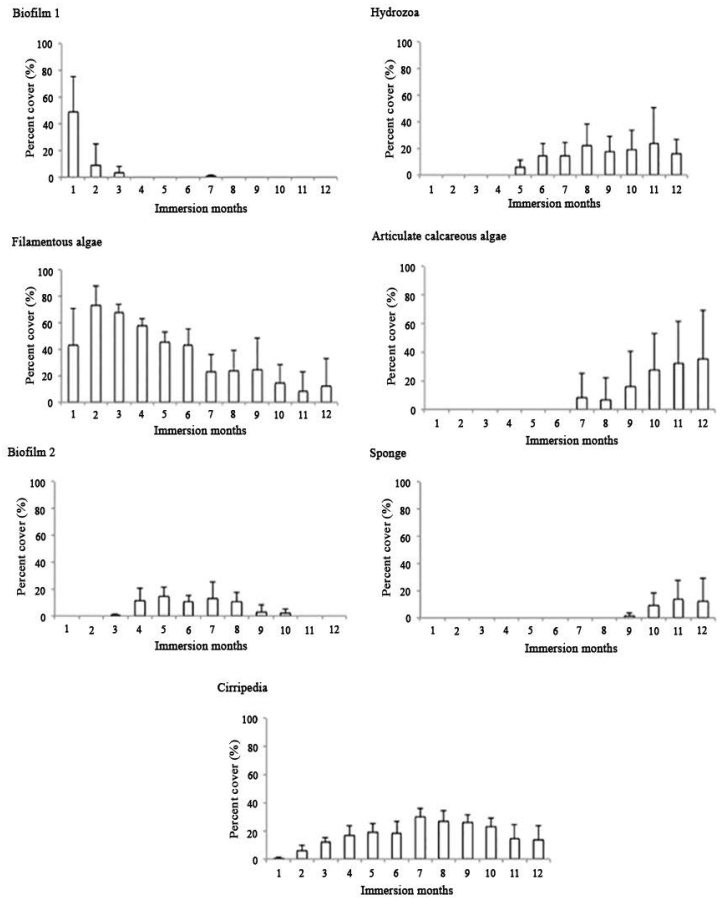

Figure 4. Mean values and standard deviation of the percent cover of the most representative fouling organisms over the 12-month period in Arraial do Cabo, Rio de Janeiro State, Brazil.

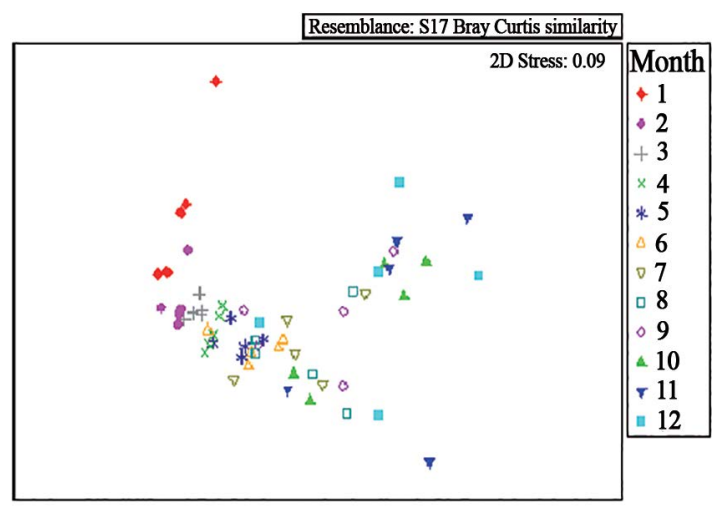

Figure 5. Non-metric multidimensional scaling plot of the fouling community in each sampling period $(1,2,3, \ldots 12$ months).

from 1 to 6 months and from 7 to 12 months (Figure 6a). At an $80 \%$ level of similarity, the formation of five groups was evident, and they represent the successional stages (Figure 6a). The first group (A: $\mathrm{S} \Delta=62.3 \%$ ) included month-1, which was characterized by filamentous algae (66.5\%) and Biofilm 1 (27\%). The second successional stage (B: $\mathrm{S} \Delta=91.5 \%)$ included month-2 and month-3 and was dominated by filamentous algae (88.56\%). The third stage (C: $\mathrm{S} \Delta=40.4 \%$ ) included month-4 to month- 6 and was characterized by filamentous algae $(50.9 \%)$, bare space (16.2\%) and Cirripedia (14.5\%) as the main contributors. The fourth successional stage (D: $\mathrm{S} \Delta=61 \%$ ) included month-7 to month-9 and was mainly represented by Hydrozoa (66.5\%), filamentous algae (12.1\%) and crustose algae (9.3\%). The fifth stage (E; $\mathrm{S} \Delta=47.8 \%$ ) included the last three months of immersion and was characterized by articulated calcareous algae (33.8\%), Hydrozoa $(20.3 \%)$ and sponges $(15.5 \%)$ as the main contributors. The continuous successional trajectory was visualized by the nMDS plot (Figure 6b).

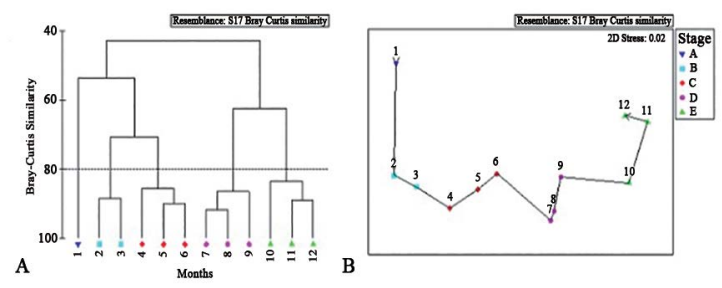

Figure 6. A. Cluster analysis (UPGMA) of the fouling community based on mean cover values of functional groups in each month of immersion at an $80 \%$ level of similarity (different successional stages are indicated by different colours). B. Non-metric multidimensional scaling plot of the fouling community in each sampling period and the successional stages (indicated by colours and letters) related to the cluster.

The five successional stages differed significantly (ANOSIM: $\mathrm{R}=0.518 ; p=0.001$ ) and showed a decreasing similarity degree (r) when compared sequentially (ANOSIM: A vs. B $\mathrm{r}=0.659, \mathrm{~B} v s . \mathrm{C} \mathrm{r}=0.539, \mathrm{C} v s . \mathrm{D}$ $\mathrm{r}=0.311$ and $\mathrm{D} v s . \mathrm{E}=0.268 ; p=0.001)$.

\section{DISCUSSION}

The intensity and frequency of seasonal upwelling events might affect the environmental variability due to particular oceanographic characteristics and also may influence the level of stress that the community experiences. In the Cabo Frio region, recording temperature every hour enabled a more accurate assessment of the effect of upwelling events at the site. Although DE MESSANO et al. (2009) recorded a weekly temperature variation of 19 to $23.6{ }^{\circ} \mathrm{C}$, in the present study we observed a higher temperature range of 13.5 to $31.5^{\circ} \mathrm{C}$ when the temperature was measured hourly. The variation in temperature, and consequently in the hydrologic parameters associated with upwelling events, was considerably higher when observed at a lower resolution, which conferred a greater environmental stress to the site. The discontinuity of the upwelling events in the Cabo Frio region was reflected in the successional trajectory of the associations, which was 
characterized as a continuous process and different from the seasonal circular pattern found at a temperate site by QVARFORDT et al. (2006).

Despite the temporal continuum in colonization, this process may be separated into stages before and after six months of immersion. The first stage is characterized by biofilm and filamentous algae. Biofilms are composed of organic matter and microorganisms such as bacteria and diatoms and serve as an attractive substrate for colonization filamentous forms (PARK et al., 2011; FONSÊCA-GENEVOIS et al., 2006). The diatoms Nitzschia and Navicula were the main components of Biofilms 1 and 2 and were also identified by DE MESSANO et al. (2009) in experimental panels placed at the same site. Filamentous algae are characterized by high growth and reproduction rates, and confer the strategies of opportunistic organisms that are usually present in early successional stages (SZÉCHY; FARIA DE SÁ, 2008; STENECK; DETHIER, 1994). The reduction of these filamentous algae along the immersion period may be related to herbivory. According to CECCARELLI et al. (2011), fish herbivory is an important mechanism that affects benthic succession. During the study, the fish Stephanolepis hispidus (Actinopterygii, Monacanthidae) was frequently observed feeding on organisms encrusted on the panels (Figure 7), and their bites on filamentous algae were evident, especially in the first months of immersion (personal observation). Numerous grazers entirely remove the filamentous and foliose forms, but few can denude larger macroalgae and even fewer can remove coralline crusts (STENECK; DETHIER, 1994). At month-9, predation was less intense and articulated calcareous algae predominated.

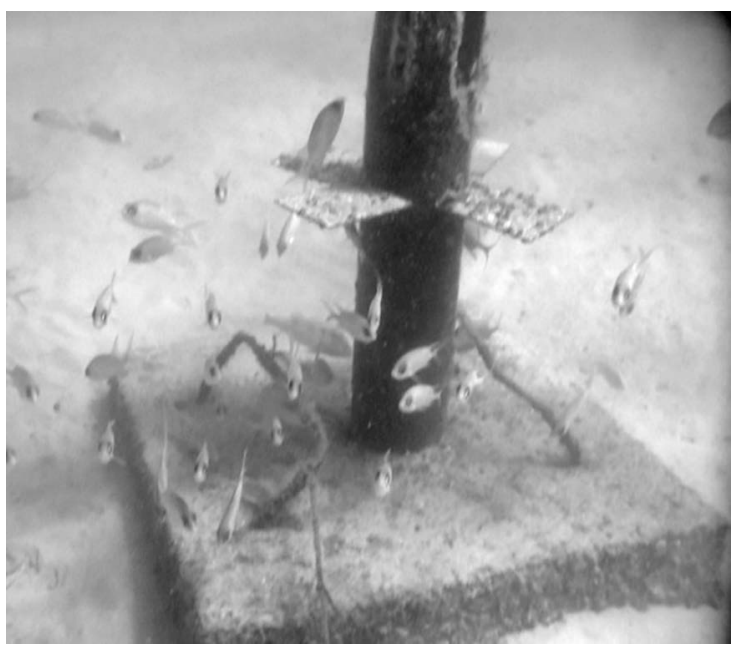

Figure 7. Biofouling multi-experimental unit used in the present study showing the fish community associated with the panels.
Starting at month-7, the associations were characterized by Hydrozoa, Cirripedia and articulated calcareous algae, although Hydrozoa typically dominate early stages of epibenthic communities (SEBENS, 1986; DE MESSANO et al., 2009). According to FIGUEIREDO et al. (2004), benthic communities may be characterized by increased stability because they have a greater abundance of coriaceous and articulated calcareous algae (e.g., Jania spp.), which are typical of the final stages of succession and corroborate our results. In the later stages, sponges and the encrusting bryozoan Schizoporella errata were recorded. These organisms have been described in advanced successional stages as interference competitors because of their ability to exclude other species from the space they occupy (SUTHERLAND, 1978; WHALAN; WEBSTER, 2014). The process of competitive exclusion as a result of dominant competitors can homogenise the community and produce a single stable state called canalised community succession (CIFUENTES et al., 2010). However, starting at month-10, two encrusting associations were identified: one was dominated by Hydrozoa, Cirripedia and filamentous algae and the other association was characterized by articulated calcareous algae, Hydrozoa and sponges.

The present study began with the assumption that even if the major mechanisms involved in the successional process of the fouling community can be determined, one alteration to the system over a short period of time is enough to modify the course of the process. Thus, it is impossible to predict the future trajectory of the community because the differences will increase with time based on the complexity of the stochastic and deterministic factors involved. The formation of distinct associations and the increase in the variability among sampling units are reflected in divergent successional trajectories, showing a patchy distribution that is usually found in natural subtidal rocky communities, where several environmental factors are responsible for generating and maintaining the mosaic pattern (MENGE et al., 2005). Therefore, the classic model of orderly and directional succession (sensu CLEMENTS, 1916; MARGALEF, 1963; ODUM, 1969) in which assemblage variability declines over time is rejected in favour of the hypothesis of multiple stable points (sensu SUTHERLAND, 1978).

The possibility that associations with different trajectories might reach a similar pattern on a time scale greater than the one used in the present study has not been ruled out. According to LEPS; REJMÁNEK (1991), temporal divergence does not prevent an eventual convergence. 
The different associations observed in the present study after 12 months of immersion are interpreted as a random grouping that is indicative of one of the many possible groups that can originate from a similar pool of species. These results emphasise the importance of sample replication. Variable recruitment and the differential ability to invade occupied substrates and resist larval invasion are common characteristics of fouling communities where recruitment and/or adult mortality produce significant changes in the structure of these communities (SUTHERLAND; KARLSON，1977; SUTHERLAND, 1984). Seasonality and environmental stochasticity add complexity to this basic rule.

Coastal upwelling is one of several mechanisms involved in the supply of larvae to coasts (SHANKS, 1995). A better understanding of the oceanographic processes that influence larval transport and dispersion on a local scale can generate more realistic estimates and consequently contribute to the successful acquisition of knowledge related to the effects of larval supply on the structure of benthic communities.

In summary, divergent successional trajectories were shown when fouling associations were initiated under the same conditions and subjected to seasonal upwelling water masses, which promoted environmental heterogeneity and led to the acceptance of the tested hypothesis. Thus, an environment characterised by seasonal upwelling provides an opportunity to evaluate the effect of temporal fluctuations of coastal oceanographic conditions, such as temperature, on benthic communities.

\section{ACKNOWLEDGEMENTS}

This work was supported by the Brazilian Agency for Research Development - CNPq/FAPERJ/PRONEX under Grant E-26/111.438/2010. We are grateful to the Biofouling Laboratory (IEAPM) team for field assistance.

\section{REFERENCES}

BRAM, J. B.; PAGE, H. M.; DUGAN, J. E. Spatial and temporal variability in early successional patterns of an invertebrate assemblage at an offshore oil platform. J. Exp. Mar. Biol. Ecol., v. 317, p. 223-237, 2005.

CECCARELLI, D. M.; JONES, G. P.; MCCOOK, L. J. Interactions between herbivorous fish guilds and their influence on algal succession on a coastal coral reef. J. Exp. Mar. Biol. Ecol., v. 399, n. 1, p. 60-67, 2011.

CIFUENTES, M.; KRUEGER, I.; DUMONT, C. P.; LENZ, M.; THIEL, M. Does primary colonization or community structure determine the succession of fouling communities? J. Exp. Mar. Biol. Ecol., v. 395, n. 1/2, p. 10-20, 2010.
CLEMENTS, F.E. Plant succession: an analysis of the development of vegetation. Carnegie Inst. Wash. Publ., v. 242, p. $1-512,1916$.

COMA, R., RIBES, M., GILI, J., ZABALA, M. Seasonality in coastal benthic ecosystems. Trends Ecol Evol., v. 15, n. 11, p. $448-453,2000$.

CLARKE, K. R.; WARWICK, R. M. Change in marine communities: an approach to statistical analysis and interpretation. 2 . Plymouth: Ed. PRIMER-E, 2001.

DE MESSANO, L. V. R.; SATHLER, L.; REZNIK, L. Y.; COUTINHO, R. The effect of biofouling on localized corrosion of the stainless steels N08904 and UNS S32760. Int. Biodeter. Biodegr., v. 63, n. 5, p. 607-614, 2009.

DEAN, T. A.; HURD, L. E. Development in an estuarine fouling community: influence of early colonists on later arrivals. Oecologia, v. 46, n. 3 , p. 295-301, 1980

DRAKE, J. A. Community-assembly mechanics and the structure of an experimental species ensemble. Am. Nat., v. 137, n. 1, p. 1-29, 1991.

DRURY, W. H.; NISBET, I. C. T. Succession. J. Arnold Arbor Harv. Univ., v. 54, n. 3, p. 331-368, 1973.

FARRELL, T. M. Models and mechanisms of succession: an example from a rocky intertidal community. Ecol. Monogr., v. 61, n. 1, p. $95-113,1991$

FIGUEIREDO, M. A. O.; BEATRIZ, M.; BARRETO, B.; REIS, R. P. Characterization of macroalgae in the marine communities of Cairuçú Environmental Protected Area, Parati, RJ - bases for future monitoring. Rev. Bras. Bot., v. 27, n. 1, p. $11-17,2004$

FONSÊCA-GENEVOIS, V.; SOMERFIELD, P. Colonization and early succession on artificial hard substrata by meiofauna. Mar. Biol., v. 148, n. 5, p. 1039-1050, 2006.

GUIMARAENS, A. M.; MORAES, A. D.; COUTINHO, R. Modeling Ulva spp. dynamics in a tropical upwelling region. Ecol. Model., v. 188, p. 448-460, 2005.

ITIS - Integrated Taxonomic Information System. Available from: $<$ http://www.itis.usda.gov>. Accessed 15 Jan 2009.

KOHLER, K. E.; GILL, S. M. Coral Point Count with Excel extensions (CPCe): A Visual Basic program for the determination of coral and substrate coverage using random point count methodology. Comput. Geosci., v. 32, n. 9, p. 1259-1269, 2006

KORDAS, R. L.; HARLEY, C. D. G.; O'Connor, M. I. Community ecology in a warming world: The influence of temperature on interspecific interactions in marine systems. J. Exp. Mar. Biol. Ecol., v. 400, n. 1/2, p. 218-226, 2011.

LADAH, L. B.; TAPIA, F. J.; PINEDA, J.; LÓPEZ, M. Spatially heterogeneous, synchronous settlement of Chthamalus spp. larvae in northern Baja California. Mar. Ecol. Prog. Ser., v. 302, p. 177-185, 2005.

LEPS, J.; REJMÁNEK, M. Convergence or divergence: what should we expect from vegetation succession? Oikos, v. 62, n. 2, p. 261-264, 1991.

MAHIQUES, M. M.; BICEGO, M. C.; SILVEIRA, I. C. A; SOUSA, S. H. D. M.; LOURENÇO, R. A.; FUKUMOTO, M. M. Modern sedimentation in the Cabo Frio upwelling system, Southeastern Brazilian shelf. An. Acad. Bras. Ciênc., v. 77, n. 3, p. 535-548, 2005.

MARGALEF, R. On certain unifying principles in ecology. Am. Nat., v. 97, n. 897, p. 357-374, 1963. 
MCCOOK, L. J.; CHAPMAN, A. R. O. Patterns and variations in natural succession following massive ice-scour of a rocky intertidal seashore. J. Exp. Mar. Biol. Ecol., v. 214, p. 121147, 1977.

MENGE, B. A.; BLANCHETTE, C.; RAIMONDI, P.; FREIDENBURG, T.; GAINES, LUBCHENCO, J.; LOHSE, D. Species interaction strength: testing model predictions along an upwelling gradient. Ecol. Monogr., v. 74, n. 4, p. 663-684, 2004.

MENGE, A., ALLISON, G.W., BLANCHETTE, C.A., FARRELL, T.M., OLSON, A.M., TURNER, T.A., VAN TAMELEN, P. Stasis or kinesis? Hidden dynamics of a rocky intertidal macrophyte mosaic revealed by a spatially explicit approach. J. Exp. Mar. Biol. Ecol., v. 314, n. 1, p. 3-39, 2005.

MITARAI, S.; SIEGEL, D.; WINTERS, K. A numerical study of stochastic larval settlement in the California Current system. J. Mar. Syst., v. 69, p. 295-309, 2008.

ODUM, E. P. The strategy of ecosystem development. Science, v. 164, p. 262-270, 1969.

PARK, S. R.; KANG, Y. H.; CHOI, C. G. Biofilm: a crucial factor affecting the settlement of seaweed on intertidal rocky surfaces. Estuar. Coast. Shelf Sci., v. 91, n. 1, p. 163-167, 2011.

PICKETT, S. T. A.; COLLINS, S. L.; ARMESTO, J. J. Models, mechanisms and pathways of succession. Bot. Rev., v. 53, n. 3, p. 335-371, 1987.

PINEDA, J.; JONATHAN, H.; SPONAUGLE, S. Larval transport and dispersal in the coastal ocean and consequences for population connectivity. Oceanography, v. 20, n. 3, p. 22-39, 2007.

PINEDA, J.; PORRI, F.; STARCZAK, V.; BLYTHE, J. Causes of decoupling between larval supply and settlement and consequences for understanding recruitment and population connectivity. J. Exp. Mar. Biol. Ecol., v. 392, p. 9-21, 2010.

QVARFORDT, S.; KAUTSKY, H.; MALM, T. Development of fouling communities on vertical structures in the Baltic Sea. Estuar. Coast. Shelf Sci., v. 67, n. 4, p. 618-628, 2006.
SEBENS, K. P. Spatial relationships among encrusting marine organisms in the New England subtidal zone. Ecol. Monogr., v. 56, n. 1, p. 73-96, 1986.

SHANKS, A. L. Mechanisms of cross-shelf dispersal of marine invertebrates. In: MCEDWARD, L. R. (Ed.). Ecology of Marine Invertebrate Larvae. Boca Ratón: CRC Press, 1995. p. 323-367.

STENECK, R. S.; DETHIER, M. N. A functional group approach to the structure of algal-dominated communities. Oikos, v. 69, p. 476-498, 1994.

SUTHERLAND, J. P. Functional roles of Schizoporella and Styela in the fouling community at Beaufort, North Carolina. Ecology, v. 59, p. 257-264, 1978.

SUTHERLAND, J. P. The structure and stability of marine macrofouling communities. In: COSTLOW J. D.; TIPPER, R. C. (Eds.). Marine Biodeterioration: An Interdisciplinary Study. Maryland: United States Naval Institute, 1984. p. 202-206.

SUTHERLAND, J. P.; KARLSON, R. H. Development and stability of the fouling community at Beaufort, North Carolina. Ecol. Monogr., v. 47, p. 425-446, 1977.

SZÉCHY, M. T. M.; FARIA DE SÁ, A. D. Seasonal variation of macroalgal epiphytism in a Sargassum vulgare C. Agardh (Phaeophyceae - Fucales) population from Ilha Grande Bay, Rio de Janeiro. Oecol. Bras., v. 12, p. 299-314, 2008.

VALENTIN, J. L.; ANDRÉ, D. L.; JACOB, S. A. Hydrobiology in the Cabo Frio (Brazil) upwelling: two-dimensional structure and variability during a wind cycle. Cont. Shelf Res., v. 7, p. 77-88, 1987.

WHALAN, S.; WEBSTER, N. S. Sponge larval settlement cues: the role of microbial biofilms in a warming ocean. Sci. Rep., v. 4, p. 1-4, 2014.

WIETERS, E. A.; BROITMAN, B. R.; BRANCH, G. M. Benthic community structure and spatiotemporal thermal regimes in two upwelling ecosystems: comparisons between South Africa and Chile. Limnol. Oceanogr., v. 54, n. 4, p. 1060$1072,2009$. 